\title{
НАВЧАЛЬНИЙ ПРОТОКОЛ ПАТОЛОГОАНАТОМІЧНОГО ДОСЛІДЖЕННЯ ЯК УЗАГАЛЬНЮЮЧИЙ КРИТЕРІЙ ЯКОСТІ ЗАСВОЄННЯ МАТЕРІАЛУ СЕКЦЙНОГО КУРСУ
}

Ю. М. Орел

\author{
ДВНЗ “Тернопільський державний медичний університет \\ імені I. Я. Горбачевського МОЗ Украӥни”
}

\section{TRAINING REPORT OF PATOANATOMICAL RESEARCH AS A SUMMARIZING TEST OF THE LEARNING QUALITY OF SECTIONAL COURSE STUDYING}

\author{
Yu. M. Orel \\ SHEI "Ternopil State Medical University by I. Ya. Horbachevsky of MPH of Ukraine”
}

\begin{abstract}
У статті розглянуті окремі аспекти викладання секційного курсу. Ця навчальна дисципліна займає важливе місце в програмі підготовки лікаря, оскільки забезпечує формування клінічного мислення, визначає тактику поведінки і засвоєння алгоритму діяльності для вирішення професійних завдань на основі клініко-анатомічних зіставлень. Проведено аналіз цілей, змісту, завдань і методології написання навчального протоколу патологоанатомічного дослідження, як важливої форми роботи студента, що сприяє синтетичному узагальненню і структуризації засвоєної ним інформації, а також дозволяє викладачу об'сктивно оцінити рівень здобутих знань і навиків.
\end{abstract}

In the article certain aspects of teaching sectional course were reviewed. The discipline plays an important role in education of a doctor as provides the background for clinical mind set, determines the tactics of professional behavior and adoption of some algorithms of practical skills on the base of clinical and anatomical comparison. There were analyzed the main aims, contents, tasks and methodology of writing teaching pathology record as an important form of student's education which helps in synthesis and conformation of received information as well as allows the teacher to rate objectively the level of obtained by students knowledge and skills.

Вступ. В умовах реформування медичної освіти основною рисою навчання у вищих навчальних закладах стає процес самостійного поглиблення студентом професійних знань та навичок, який спрямовується викладачем у рамках вимог та тенденцій Болонського процесу $[1,2]$. Важливим $є$ і впровадження нових методик оцінювання, що, зокрема, реалізується на кафедрі патологічної анатомії з секційним курсом та судової медицини ТДМУ імені І. Я. Горбачевського [3].

Секційний курс (СК) - одна з тих навчальних дисциплін, котрі, незважаючи на незначну кількість академічного часу, виділеного на їх опрацювання, займають важливе місце в програмі підготовки фахівців у вищих навчальних медичних закладах. Це й не дивно, адже метою вивчення СК є формування клінічного мислення, тактики поведінки і засвоєння алгоритму діяльності лікаря для вирішення професійних завдань на основі клініко-анатомічних зіставлень [4]. Саме тому викладання цього предмета повинно базуватися на уніфікованих уявленнях про фундамен-

() Ю. М. Орел тальні основи клініко-анатомічного аналізу та бути достатньо диференційованим при висвітленні аспектів, пов' язаних зі специфікою різних клінічних спеціальностей, що дає змогу якісно підготувати майбутніх лікарів до взаємодії з патологоанатомічною службою задля ефективної роботи системи практичної охорони здоров'я $[5,6]$.

Знання, здобуті під час аудиторних занять із СК та самостійно, студент практично застосовує при написанні протоколу патологоанатомічного дослідження (ППД), що обумовлює важливість і актуальність цього фрагмента навчального процесу.

Метою даної роботи є аналіз цілей, змісту, завдань i методології написання навчального протоколу патологоанатомічного дослідження, як важливої форми роботи студента, що сприяє синтетичному узагальненню і структуризації засвоєної ним інформації, а також дозволяє викладачу об'єктивно оцінити рівень здобутих знань і навиків.

Основна частина. Протокол патологоанатомічного дослідження - це форма первинної облікової 
документації, затверджена наказом МО3 України [7]. Він в обов'язковому порядку складається у кожному випадку патологоанатомічного дослідження.

Типова програма вивчення дисципліни СК передбачає оформлення навчального ППД на підставі даних автопсії, при проведенні якої були присутні студенти, та результатів гістологічного й інших допоміжних методів дослідження. Для урізноманітнення тем, а також з метою демонстрації патоморфологічної картини рідкісних нозологій чи захворювань 3 нетиповим перебігом в якості первинного матеріалу для написання протоколу може бути використаний навчальний відеофільм або віртуальна навчальна програма.

Ціль, що ставиться перед студентом при написанні навчального ППД, - верифікувати патологічні процеси, що мали місце у померлого, та пояснити, яким чином вони призвели до летального наслідку. Першим етапом реалізації цього завдання є опис стану органів і тканин з подальшим висвітленням цієї інформації в текстовій частині протоколу. Тут докладно, послідовно та об'єктивно перераховуються всі зміни, виявлені при розтині трупа. Спершу описуються результати зовнішнього огляду тіла, потім - стан порожнин, характер розміщення внутрішніх органів. Опис нутрощів здійснюється посистемно, при цьому патологічні зміни органів та тканин повинні характеризуватися об'єктивно, без нав'язування особистої думки студента, з використанням загальноприйнятих одиниць вимірювання та різновидностей кольорів, уникаючи порівнянь з розміром та кольором тих чи інших предметів. Неприпустимим є можливість трактувань, що суперечать одне одному. Обов'язково описуються і візуально незмінені внутрішні органи, однак при цьому можна обмежитися визначенням їх масометричних параметрів та вказівкою на відсутність видимої патології.

Важливу, а часом і вирішальну роль у постановці патологоанатомічного діагнозу відіграють результати гістологічного дослідження, тому обов'язковими є забір матеріалу для некропсії і відображення отриманих результатів у ППД. Для більшої достовірності патологоанатомічного діагнозу доцільним є застосування допоміжних методів - цитологічного, імуногістохімічного, бактеріологічного тощо. Навіть якщо в реальних умовах вони не застосовуються в патологоанатомічному бюро чи відділенні, студент може вказувати їх у навчальному ППД, зазначивши при цьому прогнозовані результати та їх місце у форматі патоморфологічної доказовості діагностованої хвороби.

Наступним етапом роботи студента є аналіз, узагальнення і синтез клінічних даних, результатів автопсії, некропсії та допоміжних методів дослідження 3 наступним формулюванням патологоанатомічного діагнозу та складанням патологоанатомічного епікризу з виділенням безпосередньої причини та механізмів смерті, порівнянням клінічного та патологоанатомічного діагнозів, встановленням характеру та причин недоліків у наданні медичної допомоги.

Патологоанатомічний діагноз формулюється за нозологічним принципом, з урахуванням існуючих нормативних документів Міністерства охорони здоров’я і вимог Міжнародної статистичної класифікації хвороб та споріднених проблем охорони здоров'я Десятого перегляду (MКX-10). Діагноз обов'язково структурується із врахуванням патогенетичної послідовності патологічних процесів, при цьому виокремлюються наступні рубрики.

Основне захворювання - нозологічна одиниця, яка у відповідності з класифікацією та номенклатурою захворювання сама по собі чи внаслідок ускладнення виявилася причиною смерті, еквівалентом нозологічної одиниці можуть бути медичні заходи, котрі обумовили летальний кінець внаслідок побічних реакцій чи ускладнень, що розвинулися під час них, та виявилися причиною смерті. Слід наголошувати на необхідності перерахувати найбільш виражені морфологічні прояви основного захворювання після зазначення його нозологічної форми. Така деталізація діагностичних критеріїв у рубриці “основне захворювання” не характерна для клінічного діагнозу і тому часто випускається з уваги студентами.

Ускладнення основного захворювання (оперативного втручання, медичної маніпуляції) - це патологічний процес, синдром, нозологічна одиниця, які безпосередньо чи опосередковано пов' язані з основним захворюванням патогенетично та погіршили його клінічний перебіг. Їх перелічують у хронологічній послідовності, з врахуванням взаємозв'язків у танатогенезі.

Супутні захворювання - патологічні стани, які етіологічно та патогенетично не пов'язані з основним захворюванням та не мали важливого впливу на смертельний наслідок.

У розділі “Помилки клінічної діагностики" навчального ППД аналізується розбіжність клінічного та патологоанатомічного діагнозів за кожною з трьох згаданих вище рубрик, а також визначаються причини, що іiі обумовили. Окремою позицією констатується пізня діагностика основного захворювання чи смертельного ускладнення.

Важливим розділом навчального ППД є клінікопатологоанатомічний епікриз. Часто він помилково сприймається студентами як простий перелік клінічних та патологоанатомічних даних. Насправді, 
у цьому розділі ППД на основі зіставлення клінічних та патоморфологічних даних необхідно у лаконічній формі чітко вказати, на що хворіла людина, які патогенетичні зв'язки існують між виявленими в неї захворюваннями та патологічними процесами, чому лікування було неефективним, який характер та причини недоліків надання медичної допомоги, якими були механізми танатогенезу та безпосередня причина смерті. Під останнім поняттям мається на увазі патологічна реакція, процес, синдром, нозологічна одиниця, які призвели до незворотних змін у функціях життєво важливих органів, безпосередньою причиною смерті може бути як основне захворювання, так i його ускладнення. Ступінь відображення кожного із зазначених питань у патологоанатомічному епікризі не регламентується і в кожному конкретному випадку може відрізнятися.

Питання оптимізації вищої медичної освіти в Україні нерозривно пов'язане із впровадженням у навчальний процес основ доказової медицини [8]. Тому на кафедрі патологічної анатомії з секційним курсом та судової медицини ТДМУ імені І. Я. Горбачевського розроблено систему рівнів достовірності в патоморфології та формат патоморфологічної доказовості тієї чи іншої хвороби. Ця інформація висвітлюється в окремому розділі навчального ППД. Студент повинен визначити код хвороби за МКХ-10, надати інформацію про епідеміологію та летальність, а також систематизувати виявлені патоморфологічні зміни. При цьому диференціюються високий (специфічність макроскопії, мікроскопії, гістохімії, імуноморфології, цитохімії) та помірний (неспецифічні прояви) рівні достовірності.

Перевірка якості оформлення навчального ППД здійснюється викладачем наприкінці вивчення СК. Студент при цьому повинен надати обгрунтовані відповіді на зауваження та запитання стосовно виконаної ним роботи, тобто відбувається захист навчального ППД. Оцінки, які студент отримує за написання протоколу та його захист, впливають на загальну суму балів за модуль.

Висновки: 1. Оформлення навчального протоколу патологоанатомічного дослідження, в якому аналізуються і узагальнюються результати посмертного патоморфологічного дослідження, дозволяє студенту реалізувати активне сприйняття навчального матеріалу під час практичних занять із секційного курсу, допомагає поглибити та закріпити набуті знання, розвиває аналітичний та системний підхід до проблемних питань патологоанатомічної служби як невід'ємного структурного підрозділу системи охорони здоров'я.

2. Навчальний протокол патологоанатомічного дослідження можна розглядати як узагальнюючий критерій якості засвоєння навчального матеріалу з секційного курсу, адже підготовка і написання протоколу, як різновид самостійної творчої роботи студента, сприяє синтетичному узагальненню і структуризації засвоєної ним інформації, а також дає змогу викладачу об' єктивно оцінити рівень здобутих знань і навиків.

\section{Списоклітератури}

1. Ефективність поєднання традиційних форм навчання із засадами Болонського процесу у доклінічній підготовці лікарів / М. М. Багрій, Н. М. Воронич-Семченко, О. Г. Попадинець [та ін.] // Галицький лікарський вісник. - 2010. - T.17, № 1.-C. 89-91.

2. Трач Росоловська С. В. Особливості організації та проведення навчання англомовних іноземних студентів на курсі судової медицини ТДМУ імені І. Я. Горбачевського / С. В. Трач Росоловська // Медична освіта. - 2013. - № 4. C. 72-74.

3. Сельський П. Р. Обгрунтування доцільності застосування дистанційного оцінювання знань з морфології як складової підготовки висококваліфікованого спеціаліста / П. Р. Сельський, Я. Я. Боднар // Запорож. мед. журнал. 2013. -№2.-С. 119-120.

4. Романов В. С. Биопсийно-секционный курс / В. С. Романов, А. А. Артифексова. - Нижний Новгород : Изд-во НГМА, 2009. $-85 \mathrm{c}$.

5. Решетнікова О. С. Проблеми викладання секційного курсу в медичному ВНЗ / О. С. Решетнікова, О. В. Телешова, О. В. Зінченко // Актуальні питання теоретичної меди-

цини. Актуальні питання клінічної медицини. Клінічні та патогенетичні аспекти мікроелементозів. Actual problems of fundamental and clinical medicine (in English) : матеріали наук.-практ. конф. студентів, молодих вчених, лікарів та викладачів/відп. за вип. Л.Н.Приступа.-Суми:СумДУ,2012.-С.41.

6. Крылов Ю. В. Новые подходы к преподаванию биопсийно-секционного курса / Ю. В. Крылов, С. В. Малашенко, О. В. Лесничая // Здравоохранение. -2013. - № 9. C. $47-51$.

7. Про затвердження форм первинної облікової документації та інструкцій щодо їх заповнення, що використовуються у закладах охорони здоров'я незалежно від форми власності та підпорядкування : наказ МОЗ України № 110 від 14.02.12.

8. Дронов О. І. Впровадження викладання основ доказової медицини в навчальний процес на кафедрі загальної хірургії / О. І. Дронов, І. О. Ковальська, О. А. Скамаровський // Вісник Української медичної стоматологічної академії.-2008. - Т. 8, № 1-2.-С. 296-299.

Отримано 09.02.15 